\title{
So What if She Can't Dance and Sing: A Testimony from the afrohabanera
}

\author{
Dawn Duke • University of Tennessee, Knoxville
}

\begin{abstract}
From the early 1990s, a new film gained momentum in which there were no actors, i.e. contracted, paid, and famous, rather ordinary people, residing at the fringes of society, who momentarily were on camera, guided by a director determined to film realistic images. Cidade de Deus (Brazil), Pixote: a lei do mais fraco (Brazil), La vendedora de rosas (Colombia), Rodrigo D (Colombia), and Ratas y ratones (Ecuador) are examples. There is little footage about Cubans during the Special Period (1989-1995). Further, until then no production had directly and realistically focused on Afro-Cuban women. Rolando Díaz's 1998 production, Si me comprendieras (If You Could Understand Me) offers an opportunity to contemplate her version of the Special Period. Havana comes alive, embedded in that artistic technique of presenting the black female body as the medium for navigating issues such as culture, revolution, and nationhood. While music and dance serve as the point of entry for displaying the fabric of society, they transition into tools that assess how empowered Afro-Cuban women have become during and after the Revolution, especially at the time of the filming thirty years later.
\end{abstract}

S i me comprendieras (If You Could Understand $\mathrm{Me}$ ) is a 1998 testimonial documentary-film (or docudrama) by Cuban director Rolando Díaz that takes us into the lives and thoughts of at least eight women of African descent who reside in Havana. It is a film that provides us with an opportunity to examine the cultural presumption at the core of this cinematographic display with regard to the Afro-Cuban woman - that she has an innate ability and inclination to sing and/or dance, that she is spontaneously provocative and sensual, and that she usually is part of those social classes facing economic and financial challenges. The director makes it clear that this was a planned selection, even as he seems not to have recognized that his idea was the result of preconceived ideas rooted in relations of colonialism and in the tendency to fantasize about her body, envisioned as a site of talent and exoticism. This study argues that such an approach is not new, as illustrated by character sketches of similar figures in the Spanish Caribbean poetic movement of the early 2oth century known as negrismo, and also by the deployment of rumba, known as the sensual, rhythmic, and widely popular dance with African roots. ${ }^{1}$ Critical perspectives on these two cultural phenomena assess to what extent they were coopted into the revolutionary agenda in its determination to build a sense of national pride. By way of a woman-centered perspective, it becomes possible to argue that negrista poetry, rumba, and this film, share the same problematic rendering of black female portrayal, even as this is the first film that facilitates the voicing and representation of a spectrum of Afro-Cuban women who, in their own way, are critical and question the toll that revolutionary ideals have on their lives.

Flamboyant, colorful imagery, rhythm, percussion, and words or phrases representing Afro-Cuban and popular Cuban language styles converge in negrista writing and are critical components for its success as representative of Afro-Cuban culture. The use of exaggeration as a literary technique created distorted poetic images even as these symbolized an important breakthrough in a literary legacy that, until then, had never included in a significant way the Afro-Cuban subject. Given the playful, often dismissive tones of the poetry, there are tensions between poetic form and the central character's social existence, marred as it still was at the beginning of the twentieth century by the legacy of slavery. Equally troubling is the way in which, in various verses, configurations of Africa's contributions to the formation of national racial identity take shape through the 
objectification of the black female body. In similar fashion, the song-dance premise that drives the film's storyline resuscitates such bodily focus, a pillar in this film's provocative version of what it means to be black towards the end of revolutionary idealism.

Cuban negrista poetry provides a frame of reference in the way it portrays the black body. There are a wide range of poems that attest to the link between the Afro-Cuban female body and visions of nationhood. These include: Nicolás Guillén's "Mulata," Alfonso Hernández Catá's "Rumba," Emilio Ballagas' "Elegía a María Belén Chacón," and Marcelino Arozarena's "La comparsa del maja." What stands out is the masculine gaze on the female Other, her physical attributes, rhythmic gyrations, facial features, and skin color. These patterns are contagious and repeat themselves in several poems, appearing in close connection with the Afro-Cuban dance rumba, known for its implied flirting and the sensuous movements of the female dancer. On one hand, the negrista poetic tradition is rich in its recovery and expansion of Cuban folkloric representations and the promotion of a tropical vision of national self, on the other it has a damaging effect given the role the female figure must play. Poetry invents a figure that is pleasurable to the masculine gaze, one he will potentially desire and perhaps ultimately possess. Alfonso Camín's "Danzón de María Belén," José Zacarías Tallet's "La rumba," José Antonio Portuondo's "Rumba de la negra Pancha," and Ramón Guirao's "Bailadora de rumba" are poems whose imagery clearly illustrates the ambiguous play between cultural celebration of folklore and the exploitation of the woman of African descent. ${ }^{3}$

Explicit and sensual verses reveal a literary rebelliousness not previously visible in poetry. Negrista poems bring to center stage the gyrating figure of the black or mulatto woman. For special effect, animal-like imagery together with use of onomatopoeia and nonsense words implies the naturalistic tendencies of the persona, even as they seek to capture the rhythms of percussion instruments. Williams critiques the depiction as part of a legacy of degrading perception of the African woman's body, dating back to eighteenth-century European thought. She describes poetry as reverting back to ideology that places the black female body in direct negative contrast with the white woman, simultaneously lowering her to the status of female animals and associated with sexual misconduct and barbarism. ${ }^{4}$ There is consistent correlation between female aesthetic depiction and nationalistic sentiment. Williams (63) and Mansour (172-81) point to the exploitation of the black female body to promote a nationalistic discourse of Cubanness, by way of Africa. Young critiques the inevitable objectification that accompanies the nationalizing intention. She sees it as contributing to a long tradition of poetic appropriation and abuse, for the woman continues as "one more natural resource, sought after, cultivated and exploited for the pleasure and satisfaction of the master" (Young 140). It proves to be no more than "the establishment of a relationship between writers and poetic subjects based on voyeurism and sexual desire" (Williams 69).

In style and objective, the film displays similar characteristics. Portrayals of these Afro-Cuban women take place against the rather difficult backdrop of life in Cuba during the early 1990 s known as the Special Period, a detail that has implications for the perspectives and Havana landscapes that are filmed. It is a well-intentioned and strategic production that has gained value over time, now serving as a visual record of those times marked by dire economic circumstances. As the camera zooms in and out, we meet these women individually and as a group, in a process of singular and collective voicing from which their diverse meaningful stories emerge as verbal manifestations coming from those who are very rarely heard. These stories are problematic in the way they clarify weaknesses within the nation's ideological agenda. As life stories, they aptly reveal women's historical and cultural vulnerabilities that even revolutionary Cuba did not address. Strategically, they uncover systemic shortfalls and failures that, over time, continue to detrimentally impact this community (Madrazo Luna 2).

A cinematographic production funded by ICAIC (Cuban Institute of Cinematographic Art and Industry), it displays certain characteristics that mark that country's film industry (Cicero Sancristóbal 320). The set is of course the iconic space of the capital city Havana. The camera moves around freely and intrusively, filming places and people, listening in on conversations, taking liberties with people's appearances, actions, habits, words, and lives. The moving images are supported by a narrator who sardonically describes the city landscape and explains why he chose to film there. Reality and fiction combine in a production that is both revelatory and critical of contemporary Havana, even as public spaces are the spheres of choice for this production. It is a unique film, potentially theatrical, an effect achieved by the way it cultivates the ongoing myth that everything in Havana finds resolution in song and dance. It is spontaneous, yet it is also staged. Intermittently throughout the production are excerpts from a play with an all-black cast. The main layer comprises the selection, training, and engaging of those candidates who will form the group, and whose stories are featured. The filming thrives on spontaneous revelations about their lives, their dreams, and their day-to-day challenges (Pérez and Rodríguez-Mangual, 192). Havana comes alive through the experiences of these Afro-Cuban women, in many ways reproducing that deeply-rooted literary, potentially stereotypical technique of presenting them physically, as if this were the medium for arriving at certain conclusions about broader, more urgent matters of importance, such as those related to territory, nation, and ideology. Yet, there is something beyond that in this production. For while music and dance serve as the initial point of entry for penetrating the fabric of Havana society, it becomes possible to assess 
just how empowered they are at this moment in time, positioned at the intersection of race, class, and gender during a critical period of revolutionary decline.

Howe analyzes current changes among critics, writers, and artists, in what she prefers to describe as Cuba's post-revolutionary historical phase (14).

With the advent of the Special Period, intellectuals still residing on the island audaciously began to explore the chasm that separated the seedy reality they inhabited from the ideal socialist island depicted in the government's propaganda. Cuban intellectuals were increasingly unwilling to deny that the economic and social crisis was real and that its impact was transforming cultural expression. (3-4)

Cicero Sancristóbal confirms the liberating effect such loss of government financial support had on ICAIC, for it forced the agency to subsidize its own existence and seek alternative, often international, funding and technical support that, in turn, led to a reduction in State-imposed vigilance, censorship, and sanctions.

Además de las mulatas y los paisajes tropicales inevitables, algunas de las coproducciones de la época cargaban la mano en la crítica de la situación social, y el panorama del séptimo arte en la Isla, de cierta paradójica manera, se revitalizó extraordinariamente. (320)

Such changes represent a new approach, one that today is less fearful of challenging the government-mandated restrictions, being placed on open artistic critique and discussion of diversity issues, racism, and LGBTQ+ experiences in Cuba. When interviewed, Tomás Gutiérrez Alea examined the relationship between the more orthodox wing of the State and ICAIC (Chanan "We are Losing" 49). During that period, certain cultural patterns and behaviors not conforming with the preferred national identity were condemned as revolutionary digressions or problems of sovereignty. Such cultural patterns, including Afro-Cuban identities, homosexual identities, and political non-conformism, are integral conflictive issues that can no longer be ignored, for as Si me comprendieras indicates, encroaching changes have caused the resurgence of socio-economic difficulties re-introducing class-based distinctions between those who are thriving and the masses that are not, which is where most Afro-Cubans tend to be located. ${ }^{5}$

When interviewed on October 12, 2018 by Dean Luis Reyes of Altercine Productions, Rolando Díaz declared, "Soy un cineasta cubano de Cuba" [I am a Cuban filmmaker from Cuba] (Díaz "Interview with Dean Luis Reyes"). A longstanding Cuban director, Díaz has left his mark on ICAIC and is fully recognized as one of the prominent film producers of the revolutionary period (Chanan, Cuban Cinema 32, 410-412).
He spoke about state-driven censorship of his major cinematographic projects during the Special Period (1989-1994). Cuban authorities and ICAIC have over the years displayed political doubt of his intentions and nationalism, stemming from his status as a repatriated citizen, returning home after a successful sojourn in Spain during which his documentary El largo viaje de Rústico was nominated for the distinguished 1994 Goya film award, albeit, as a Spanish (not Cuban) production. In many ways, this questioning of his loyalties has marked his professional career as a film director.

He does recall how refreshing it was to film in Spain, an experience that allowed him to bask in a sensation of freedom; "me permitió absorber, como una esponja, cómo funcionaban las cosas en otros mundos, me había animado a concebir la idea de ser independiente" (Díaz "Interview with Dean Luis Reyes"). His interview describes the challenges he faced upon returning to Cuba to work under the directorship of ICAIC. His overwhelming difficulty was the censorship of his film Melodrama released in 1995, probably his most successful production. He speculates that he was marked back then as "disobedient", having made the decision to produce Cuban film while living and working in Spain (Díaz "Interview with Dean Luis Reyes").

Díaz identifies Si me comprendieras as the first independent Cuban film produced in Cuba and it had a very spontaneous trajectory. In 1997 in Havana, he was offered the opportunity to produce and direct a television series called "Cómo se hace el cine en Cuba" (Díaz "Interview with Dean Luis Reyes"). Under the umbrella of this project (to a certain extent, unauthorized), he put together a second and separate team that filmed what later developed into Si me comprendieras. He describes it as a spontaneous endeavor arising out of a personal desire to film the confluential topics of race and the Afro-Cuban female experience. Filming was completed with a tiny crew and in fourteen days of intense shooting in 1997. Díaz views his title as allegorical in nature, and the plot as providing Cuba's inhabitants with a chance to contemplate their reality.

It proved to be groundbreaking and innovative, a huge success. An important contribution to contemporary Cuban film industry, Si me comprendieras was presented at the 1999 Amsterdam Film Festival, the 1999 Toronto Film Festival, and the 1999 Berlin Film Festival. It was nominated for a prize at the 2oth International Film Festival of the Nuevo Cine Latinoamericano (New Latin American Cinema) held in December 1998. Known as the Premio Coral (Coral Award), it is an annual independent film festival held in Havana. In his interview with Reyes, Díaz indicated subtle tactics and forms of censorship worked to shroud the film's prominence, even as, going by audience and jury reactions, it was a favorite of the crowd. In the end, it received the Jury's Special Mention, a prize he was not allowed to climb on stage and accept ("Cronología de Festivales del Nuevo Cine Latinoamericano"). The film subsequently participated 
in more than twenty international film festivals receiving various awards and recognitions; however, it was never shown in Cuba again. He admitted that he never gave ICAIC a copy for local distribution and showings, skeptically believing that it would not have been used anyway (Díaz "Interview with Dean Luis Reyes").

In many ways, Díaz's role as director allowed him to impose and project his perspective of his country's reality on screen, even as he remained behind the camera. The nature of the questions put to passersby and the imaging of Havana - buildings, neighborhoods, families of the female actors - designed a discourse of difficulties, challenges, human potential, and sentimental nostalgia. He commissioned the band los Van Van to produce the main musical theme to which the girls danced. Running for 87 minutes, the production is special, given that the narrating style, while light-hearted and entertaining, is at the same time strategic. Irrespective of the challenges, the voice of the narrator insists on preserving his original plan, i.e. to make a film about music.

There are three juxtaposed cinematographic levels that appear randomly throughout the film. The first level consists of a panoramic perspective of the urban space sustained by popular commentary. It reinforces the idea of a collaborative production, supported by the spontaneous participation of many unidentified individuals who simply seemed drawn to a camera, as it captured their concerns, warm spirit, and perseverance. The narrator's voice is light-hearted, the city dweller's not always. The malecón, the decaying buildings, the bicitaxis, even the now defunct camello (a very uncomfortable form of public transportation shaped like a truck-trailer on wheels) are brought together in a landscape that is tropical, attractive, romantic, and varied, even as it is challenging for its permanent inhabitants.

The film thrives on live footage; indeed the narrator declares that there is no established filming site, script, or professional actors, and very limited resources. In the end, it is his presence behind the camera and his voice that will hold the action together. Images of ugliness and difficulty (poor wages, precarious water supply, bad housing, and food shortages) intermingle with displays of frustration and discontent as speculations of corruption, mismanagement, and inefficiency are laid squarely at the door of those in office. Are these counterrevolutionary manifestations? They are manifestations of disgust at the low levels to which legitimate citizens have sunk. The lack of overt anti-revolutionary rhetoric finds compensation in the very visible human distress that speaks for itself; it is visually evident that the system has failed them.

The second level engages screen with performance. Embedded in the film is a fictional representation of teatro negro [black theater], and sporadically the film releases excerpts from a play that is very critical of racism in Cuba. The company seems to be associated with Flor, one of the women featured in the film. The actors are all Afro-Cuban and, by way of caricature, irony, and exaggeration, stubbornly defy the odds and subvert officialdom's posture of colorblindness to engage the topic and their creativity to do what they most love, i.e. perform. The plot is simple; it's about a group of actors criticizing the fact that very few Afro-Cuban actors are allowed to participate in the professional performing arts. There is a definite process of intra-textuality here, for the very art world within which they operate is the one that marginalizes them, even as they use it as a mechanism for critically declaring their awareness of it, their willingness to fight this exclusion, and the autonomy they enjoy doing so. The message has a deeper purpose, given the way it uncovers a serious problem in the performing arts in Cuba by way of satirical enactment. They are not allowed to produce a theatrical production about racism. Sarduy and Stubbs describe the similar experiences of actress Elvira Cervera, actor Alden Knight, and film director Gloria Rolando, all of whose stories follow a similar line, yet who by their own efforts and perseverance have managed to develop their art (11-12). Teatro negro's performance is a critical social commentary, involving lines such as "hay fear en el ambiente!", interspersed with rhythmic movements and chants in a corporal manifestation in defiance of censorship and silencing. This staging of racialized discourse feeds into the third and central level of the film that focuses on the interviews, the dance practices, and home visits.

The venue selected for dance practices also serves as film studio and morphs into a site of close contemplation of the actors' talents (or lack thereof) and their emotional state. La rumba is the preferred music for the choreography, and a bolero song with the same name as the film is selected to test their vocal skills. The confluence that is literature, Havana, music, and dance, provides a wealth of thematic possibilities for a film, but the decision to focus on women of color was strategic, as confirmed by the narrating voice: "La negra y la mulata cubana es la síntesis de tantas cosas ...el resultado de la exageración. Sensuales, habaneras, profundas, misteriosas, directas, musicales, imprescindibles. Un refrán popular dice que son seis meses ángel, seis meses diablo" (Si me comprendieras). Riding on the waves of historical and aesthetic objectification, these words reproduce deeply engrained myths of beauty, desire, and sensuality associated with these female subjects. This centuries-old construct unravels only partially, thanks to the film's nuanced portrayal of the reality they face in post-revolutionary Cuba.

The first interviewee is Alina, la rumbera. The director knows she can dance very well for she is by profession a cabaret performer. But can she sing? Actually, he is about to find out that she cannot. Alina is a physically very shapely and attractive mulatto woman who exploits this resource to its fullest, by virtue of her career. She is very much aware of the broad social perception of her as morally loose, visible in her reaction to the above-mentioned popular proverbial 
saying regarding women of color, but ignores it and displays self-confidence and pride in what she does. She knows the value of her physical attributes and is comfortable being who she is. Rather than allow public opinion dictate her life, she is unapologetic of her achievements, loves her work, and intends to keep dancing as long as she can.

In the midst of this demanding career, Alina, a single mother, raised a child with great difficulty, often taking her baby daughter to the cabaret where she performed at night. Now married to a white Cuban, she has a son whose skin color contrasts sharply with that of her daughter. Alina speaks candidly, explaining that most of her friends, like her daughter's father, are black. Alina has traveled abroad as an entertainer; while interviewing, she lost her place in a show which would have given her another such opportunity. She does nothing to hide her desperation in a very emotional scene in which she argues with the manager of that show, fighting for an opportunity during the hardest of times as the main income earner for an extended family that depends on her financially. Alina and her children continue to live with her parents, a situation in which many young couples find themselves.

In conversation at home with her family, Alina does not see herself as racist, utilizing as proof her own ethno-cultural mixture - "isleña, español, congo, carabalî" (Si me comprendieras). Her wavy hair, brown-to-fair complexion, straight nose, and thin lips blend with her very shapely body to produce the Latin American mulata phenotype so celebrated as the feminine symbol of this region's identity. She represents miscegenation, especially mulatez, and therefore appears as perhaps the most favorable in appearance among this group of women. She calls her father a racist for admitting that he does not like blacks and did disapprove of her first relationship. At this point, the camera, rather ironically, zooms in on the father whose features and skin color potentially indicate deep ancestral African, and maybe even Indigenous roots. Alina's daughter sits nearby, serious, quiet, unsure, clearly psychologically touched by the fact that she is different. Probably ten years old, she perceives how different she is from the rest of her family and, even though her mother tells her she is beautiful, at this tender age she is processing a distinctive social experience that, unfortunately, is not dealt with systematically. She faces difficulties in school where she is attacked or confronted with queries as to why she is so dark when her family is practically all white. Roberto Fandiño emphatically praises the production as a direct testimony revelatory of the racism that continues to permeate the country, even blaming it on the revolutionary government that for decades deactivated and censured all developments on race and racism. Attention to race as a cultural phenomenon in Cuba is a twenty-first century initiative (227).

The camera will continue this trend, highlighting the talents and lives of seven other women - Joanni the model,
Flor the actress, Anais the unemployed young woman, Belkis the working girl, Doris the nurse, Alicia the classical dancer, and finally Ivete the Soviet-trained engineer. The diverse range of talents, in terms of their ability or inability to both sing and dance, contrasts with the relative evenness in their socio-economic circumstance. The lack of sufficient housing means that the majority continue to live at home with their parents and extended family. As individuals, they are not really cushioned from the effects of socio-economic difficulty, yet in the midst of difficulty, there is no lack of hope and potential, for they are still relatively young and not disillusioned by the state of affairs.

The idealistic dark-complected Joanni poses nude in spite of her disapproving grandmother. Joanni's interview reveals her ambitions and determination to be a famous professional; indeed she dreams of becoming a supermodel like Naomi Campbell. She is convinced that, with her looks, she can attain the ultimate dream of "divisa" and "poder." Flor is the one who seems to devote her life to the greater good. Her theatrical group and her immediate project of staging a play about racism in Cuba suffer constantly from the lack of basic resources, funding, government support, approval, and recognition. Her question “icuál es el miedo?” (Si me comprendieras) confirms how race and racism continue to be taboo, even as they (black women) are surrounded by evidence of differentiated treatment and discrimination. Candidly, Flor declares that there is a huge gap between the discourse of the state and a consciousness and need among the people. Belkis, the failed entrepreneur who used to operate cranes, lives with her partner who is a white Cuban. They poured all their resources into a business venture and took a loan to invest in a paladar, or small family restaurant, which they enthusiastically operated until, faced with low profits and an inability to repay the loan, they declared bankruptcy. Indebted, jobless, and financially in the red because of the taxes, Belkis is in a state of despair.

A Soviet-educated engineer, Ivete lives in a small apartment with her children, and is about to make the radical yet practical decision to work in tourism, abandoning the engineering profession for which she so diligently prepared by spending six years in the USSR. Her obligations with the government have restricted her ability to seek alternative opportunities, and she simply cannot raise her family on the pittance she earns as a professional. Ivete's circumstances are not uncommon. Educated behind the Iron Curtin during the Cold War era, she was directly impacted by Perestroika, the demise of global Communism, and the dismantling of the Eastern Block of countries. Her education, by force of historical change and international ideological turn-about, is now obsolete. But she is resilient; her symbolic act of boarding a train that will take her to the tourist resort is both nostalgic farewell and apprehension, as she starts a new and hopefully more promising chapter in her life. The filming of Ivete's story ends here and does not reveal the reality facing 
blacks within the tourism sector. During the early nineties, this was the most profitable, sought after, and controversial job market, with the added layer that Afro-Cubans were less likely to gain employment or receive the more lucrative jobs. The reality is that Ivete's chances at prosperity are, at best, very slim.

Anais and Alicia, among the youngest members of the group, are not working, reside with extended family, and seem emotionally traumatized. They appear to be protected, in Anais's case, by her doting grandmother, in Alicia's case by her mother who dreamed of her becoming a prima ballerina and, to this end, sent her to the famous national school of dance. However, Alicia is Afro-Cuban and, as her mother suggests, this along with her low socio-economic status, makes it impossible to attain the social distinction and connections needed to be among the selected and favored performers. The grandmother and mother describe their lives, difficulties, and their relationships with their girls, among the most moving moments of the documentary, for they are the words of Afro-Cuban women who invested in the national promise, never to achieve the prosperity or success imagined. They managed to raise their girls in challenging situations; Alicia and her mother are somewhat estranged, while Anais never had the opportunity to connect with hers.

Anais was raised by her grandmother, and her interview reveals the deep and continuing hurt she feels growing up as a child with no parents. She met her father once and never again, while her mother, because of her criminal record and apparent opposition to the regime, was among those dispatched in the 1980 Mariel boat exodus to the United States. Anais was just three years old when her mother departed and was never the same again. Difficult, rebellious, stubborn, perhaps even violent, are the words her grandmother uses to describe her, and indeed, her expression seems to combine loneliness, a stubborn nature, and a hidden anger. She admits to the tremendous impact this sensation of being alone has had on her, one she continues to experience even as she tries to be normal and socialize. She struggles with commitment and trust, as seen during the dance rehearsals when, repeatedly for no apparent reason, she suddenly gives up and leaves, driven by internal bitterness, uncertainty, sadness, and an inability to endure any activity that demands too much from her emotionally. Her mother returns, but Anais cannot connect with her as too many years have passed. The lingering need for parental affection hampers her capacity to mature and develop the confidence to make something of her life. Her disengagement explains her inability to feel comfortable and relaxed in the group of girls as they go through their paces. Yet, as the camera selects her, we sense that there is tremendous potential and something very different here. Her candid explanation of her personal life, fears, and emotions uncovers a deeper awareness of internal struggles and her shortcomings. She is told that she must make a final decision whether to remain with the group or leave. Her appearance in the final performance scene is perhaps indicative of a growing maturity and steadfastness.

Remitting back to the primarily corporal portrayal of the Afro-Cuban female figure in the negrista poetry of the 1920 s and 1930s, this literary movement serves as the source of all subsequent aesthetic and cultural interlacing of rumba and women of color whose body parts (the hips, the behind, the legs) are garnished in support of nationalistic sentiments and agendas at various moments in history. Díaz's film represents one more moment, as periodically the camera captures their gyrating bodies while they execute the rumba steps. Only partially does the inclusion of their life stories (i.e. their voicing) counteracts this process of objectification. Their stories are moving, and yes, the myth of the mulata or black female entertainer becomes partially undone by the sheer force of the circumstances in which these women find themselves, and more importantly, by their own words and actions. Their multiple stories do somewhat counteract such body gazing as they describe themselves openly and in ways that emphasize their sense of personal worth in spite of economic downturn or personal trauma. The undoing of the myth of the sensual dancer thus occurs through the depictions of realistic circumstances for, as the camera shows, the glamour of filming is but a brief moment of fame. It is the women themselves who, as they describe their lives, will undo the fantasy and, while resolution of their circumstances is not possible, they do celebrate the moment for the way their voices are heard. There is a liberating effect, not in terms of an ability to change socio-economic circumstances, but more as a successful move to bring onto the screen their stories in their own words. Their empowerment through dance comes in the way it allows for their own voicing.

The practices become spaces for rupturing narrow assumptions, such as the belief that all black women are in tune with rhythms, or that the ability to dance is one of the few aspects of value that can possibly be associated with the Afro-Cuban woman. Individual circumstances vary, for while some participants place a high value on their ability to dance, others do not, and others simply cannot (dance). A shift occurs as the days go by. The individual and group practice sessions gain a greater significance. On the one hand we are made to appreciate the popular emphasis on dance as a form of entertainment, interpersonal contact, socialization, relaxation, and professional gain. On the other hand, dance transmutes into a tool facilitating our appreciation of their life stories and the positive value of this experience. As the docudrama progresses, dance becomes less meaningful as art and more as an activity for psychological healing. It provides a community, a purpose; it becomes meaningful as commitment, integrity, and enables these women to face their fears, their failures, and themselves.

The nobleness of this filmmaker's cause is not without its pitfalls. His spontaneous association of this female figure with singing and dancing reproduces the debilitating cycle 
of stereotypical profiling, i.e. domesticates or sensualizes her body, objectifies her, reduces her to a visual pleasurable manifestation for male satisfaction, or places her in the mold of an entertainer. The cinematographic strategy used to condemn conditions of life in Havana, when applied to black female characterization, is problematic in the way it materializes as a tool of her potential exploitation. His choice of how to enter her world is, therefore, a continuation of historically debilitating forms of perception; the process of Othering thus continues. He does not celebrate her intellectual potential, her yearning for success and prosperity, nor does he attempt to arrive at a deeper understanding before embarking on physical imaging and strategies consistently used in her portrayals. The filmmaker's intention, while bent on justice and truth, is incapable of escaping that mouse trap of a historically formulated white male perspective associated with Romantic abolitionist literature and negrista poetry. Sensuality is once again embedded in a worthy intention to display who they are, i.e. women whose lives are filled with challenges, resulting in a skewed cinematographic display that, labeled as a documentary, is difficult to challenge, counteract, or deny as viable and true.

The ethnographic eye of the camera singles out what men would find attractive in the enticing female contours that women like Alina and Joanni possess. Rather than condemn the male stares, comments, and catcalls these women provoke as they walk through the streets, the camera is intent on capturing the play between their image and popular street-level responses to it. The film seems to divulge and celebrate such potential irreverence as a trait of cubanía or Cubanness. Further, the women are not offended by it rather they seem to thrive on the attention, thereby giving the obvious sexual innuendos and such forms of socializing a life of their own. They cultivate their image for the way it gets them the attention and fame they seek, while, as their interviews later indicate, in no way do they deem themselves to be insulted, immoral, or socially incorrect for doing so. Consequently, there is a feminine appreciation of such public male acknowledgement of their attractiveness, even though for other women or in feminist spheres it could be deemed rude, insulting, and politically incorrect. It is a public unfiltered form of appreciation that advises them of their physical attractiveness and seems to boost their self-esteem. Further, there is a practical financial purpose, as the sensual self-imaging that they seem to be buying into offers concrete possibilities for economic gain, even prosperity. Of course all this cultural interplay does nothing to erase the problematic side to all this, which is that, for women like them, it is but a temporary state of being, with limited financial gain. Additionally, it undermines possibilities for a more serious form of socio-economic politicizing which would ultimately help them demand those structural changes needed to improve their overall state of well-being.
Race and racism are themes behind this production, however they appear controlled by state policy that encourages minimal engagement. Also, even though the film focuses on the Afro-Cuban woman, no attempt is made to directly include this topic in conversations with pedestrians or the girls and their families; rather it is the interviewees themselves who may or may not actually bring it up, revealing to what extent they are aware, and whether they feel it is an important part of their current situation. Howe's question is therefore quite relevant: "Does cultural production in Cuba reflect the reality of blacks' societal integration, or does it merely mimic revolutionary rhetoric on ideal racial harmony?" (68) One can question the local preferences, definitely in relation to certain biases, in terms of economic status and aspects of gender expectations. As this documentary indicates, there is no doubt that it is more difficult for the Afro-Cuban woman to achieve prosperity, and she is less likely to participate in spheres marked by discourses that critically engage issues of race, gender, and economics. By belonging to an environment that avoids such engagement, she is therefore silenced, prevented from addressing an issue that definitely has an impact on the quality of her existence. The process of an "erasure of color" de-politicizes the possibility of race as an issue of national debate, thereby reducing the effectiveness of artistic productions as tools for developing social consciousness and enlightenment (Howe 69).

This film serves as a reminder of where Cuba was with regard to race and racism in the 1990s, and is a good measure to assess what gains have been achieved since its release. The success of this filming project rests less on the images of Havana that remain with us and more in the way the camera was able to defy the odds as it were and zoom in on a particular female experience. The external restrictions and political processes that seem to have neutralized class and race differences in Cuba, thereby making such ventures more difficult in this sense, were overcome in a very simple and direct way. The employment of rumba offered the mechanism needed to initiate the process and guide the project beyond the focus on the external and the physical, towards the subjective, very personalized situation of these female subjects. As the film ends, we hear Omara Portuondo's version of the bolero song, "Si me comprendieras." Further, we are entertained by the dancers whose final performance to the spicy music of the popular Cuban band, los Van Van, takes place not on a stage or on an artificial movie set, but in the midst of that very space that is theirs. The densely populated street of a typical working-class Havana neighborhood is their stage, and their audience are the very people with whom they dwell. There is no triumphant socio-economic resolution or drastic transformation of their circumstances, indeed this was not the original intention. Yet, at the same time, there is a sensation (and hope) that not only have they moved on from that initial moment when their words and actions were captured on film, but also that they may have been impacted in some 
meaningful way by this small but focused interest in their lives.

\section{NOTES}

1. A Spanish-Caribbean literary movement that flourished between 1926 and 1940, Negrismo or negrista poetry celebrated the Afro-Cuban verses of predominantly Hispanic (white) male writers. (Mansour 135).

2. Morales sel. e intro., Poesía a froantillana y negrista. Puerto Rico, República Dominicana, Cuba (Universidad de Puerto Rico, Rio Piedras, 1981); Guillén, Nicolás Guillén. Obra Poética 1920-1958. Tomo 1 (Instituto Cubano del Libro, 1972); Tallet, Orbita de Jose Z. Tallet, sel. y notas Helio Orovio (UNEAC, 1969); Ballagas, Obra poética (Mnemosyne, 1969); and Guirao, Orbita de la poesía afrocubana 1928-1937 (Ucar, García y Cía., 1938).

3. Ballagas, Antología de la poesía negra hispanoamericana (M. Aguilar, 1935); Guirao, Orbita de la poesía afrocubana 1928-1937 (Ucar, García y Cía., 1938); and Mansour, La poesía negrista. (Era, 1973).
4. Williams, Charcoal and Cinnamon. The Politics of Color in Spanish Caribbean Literature (U. of Florida P.s, 2000), 53.

5. Carlos Moore (1988), Tomás Fernández Robaina (1994), Aline Helg (1995), Alejandro de la Fuente (1998, 1999, 2001), William Luis (1999, 2001), Pedro Sarduy and Jean Stubbs (2000), and Linda Howe (2004) have in-depth studies that discuss and analyze the broad cultural impact that issues of race have had on the Afro-Cuban community and on the nation as a whole, from abolition to date.

6. Foreign currency and power. The word poder in this context is not so much "power" rather a combination of "independence," "prosperity," "enrichment," and the overall well-being that comes with financial stability and comfort.

\section{WORKS CITED}

Ballagas, Emilio. Obra poética. Mnemosyne, 1969.

--- Antología de la poesía negra hispanoamericana. M. Aguilar, 1935.

Branche, Jerome. "Negrismo: Hibridez cultural, autoridad y la cuestión de la nación". Revista Iberoamericana, vol. LXV, no. 188-189, julio-diciembre 1999, pp. 483-504.

Chanan, Michael. Cuban Cinema. University of Minnesota Press, 2004.

--- "We Are Losing All Our Values: An Interview with Tomás Gutiérrez Alea." From Cuba. Boundary 2, vol. 29, no. 3, Fall 2002, pp. 47-53.

Cicero Sancristóbal, Arsenio. "Suite Habana y Si me comprendieras o el "misterio" de la recepción." Cinema Paraíso: representaciones e imágenes audiovisuales en el Caribe Hispano, edited by Rosana Díaz Zambrana \& Patricia Tomé, Isla Negra, 2010, pp. 316-335.

"Cronología de Festivales del Nuevo Cine Latinoamericano." http://www.cadenagramonte.cu/articulosver/28332:cronologia-de-festivales-del-nuevo-cine-latinoamericano. Accessed 28 October 2018.
De La Fuente, Alejandro. A Nation for All. Race, Inequality and Politics in Twentieth-Century Cuba. UNC Press, 2001.

---. "Myths of Racial Democracy: Cuba 1900-1912." Latin American Research Review, vol. 34, no. 3, 1999, pp. 39-73.

---. "Race, National Discourse and Politics in Cuba. An Overview." Latin American Perspectives, vol. 25, no. 3, May 1998, pp. 43-69.

Díaz, Rolando. "Interview with Dean Luis Reyes. 'Soy un cineasta Cubano' (Parte 2 y final).” Inter Press Service in Cuba. 12 Octubre 2018, www.ipscuba.net/espacios/ altercine/detras-de-camara/rolando-diaz-soy-un-cineasta-cubano-parte-2-y-final/. Accessed 28 October 2018.

Fandiño, Roberto. "Si me comprendieras." Revista Hispano Cubana, vol. 4, primavera-verano, mayo-septiembre 1999, pp. 227-230. www.jstor.org/stable/

Fernández Robaina, Tomás. El negro en Cuba 1902-1958. Apuntes para la historia de la lucha contra la discriminación racial. Ciencias Sociales, 1994.

Guillén, Nicolás. Nicolás Guillén. Obra Poética 1920-1958. Tomo 1. Instituto Cubano del Libro, 1972. 
Guirao, Ramón. Orbita de la poesía afrocubana 1928-1937. Ucar, García y Cía., 1938.

Helg, Aline. Our Rightful Share. The Afro-Cuban Struggle for Equality. 1886 -1912. UNC Press, 1995.

Howe, Linda. Transgression and Conformity. Cuban Writers and Artists After the Revolution. U. of Wisconsin P., 2004.

Kutzinski, Vera M. Sugar's Secrets. Race and the Erotics of Cuban Nationalism. UP of Virginia, 1993.

Luis, William. Culture and Customs of Cuba. Greenwood, 2001.

---. "Race, Poetry, and Revolution in the Works of Nancy Morejón.” Singular Like a Bird. The Art of Nancy Morejón, edited by Miriam DeCosta-Willis, Howard UP, 1999, pp. 45-67.

Madrazo Luna, Juan Antonio. "Actrices negras entre el cepo y la cama." Cubanet, vol. 18 de septiembre, 2013. https:// www.cubanet.org/articulos/actrices-negras-entre-el-cepo- y-la-cama/. Accessed 28 October 2018.

Mansour, Mónica. La poesía negrista. Era, 1973.

Morales, Jorge Luis, sel. e intro. Poesía a froantillana y negrista. Puerto Rico, República Dominicana, Cuba. U. de Puerto Rico, Rio Piedras, 1981.

Moore, Carlos. Castro, the Blacks and Africa. Center for AfroAmerican Studies, University of California, 1988.

Pérez, Fernando and Edna M. Rodríguez-Mangual. "Filmar es Silbar": entrevista con el director Fernando Pérez." Confluencia, vol. 20, no. 1, Fall 2004, pp. 188-196. www. jstor.org/stable/27923042. Accessed 7 December 2018.

Rolando, Gloria. "Stories and Images of Our People: Propositions for a Future." African Roots/American Cultures. Africa in the Creation of the Americas edited by Sheila S. Walker, Rowman \& Littlefield Publishers, Inc., 2001, pp. 348-351.

Sarduy, Pedro P. and Stubbs, Jean. "Introduction." AfroCuban Voices. On Race and Identity in Contemporary Cuba, edited by Pedro Pérez Sarduy and Jean Stubbs. U. of Florida P., 2000, pp. 1-38.

Si me comprendieras/If You Only Understood. A film by Rolando Díaz. 87 minutes. Color. Distributed by First Run Icarus Films, 1998

Tallet, José Z. Orbita de Jose Z. Tallet. Selección y notas Helio Orovio. UNEAC, 1969.

Williams, Claudette. Charcoal and Cinnamon. The Politics of Color in Spanish Caribbean Literature. U. of Florida P., 2000.

Young, Ann Venture. "The Black Woman in Afro-Caribbean Poetry." Blacks in Hispanic Literature: Critical Essays. Miriam DeCosta. Kennikat, 1977. 137-42. 